\title{
CpG-Oligodeoxynucleotides Improved Irradiation-Induced Injuries by G-CSF and IL-6 Up-Regulation
}

\author{
Pei Zhang ${ }^{\mathrm{a}}$ Suhe Dong ${ }^{\mathrm{a}} \quad$ Jiaming Guo ${ }^{\mathrm{a}} \quad$ Yanyong Yang ${ }^{\mathrm{a}} \quad$ Cong Liu ${ }^{\mathrm{a}} \quad$ Bailong Lia \\ Fu Gao ${ }^{a}$ Xuejun Su ${ }^{b}$ Jianming Cai ${ }^{a}$ \\ aDepartment of Radiation Medicine, Faculty of Naval Medicine, Second Military Medical University, \\ Shanghai, 'Department of Navy Aviation Medicine, Faculty of Naval Medicine, Second Military Medical \\ University, Shanghai, P.R. China
}

\author{
Key Words \\ Irradiation • Radioprotection • CpG-ODN • G-CSF • IL-6
}

\begin{abstract}
Background/Aims: This study investigated the radioprotective properties of three classes of CpG-oligodeoxynucleotides (CpG-ODNs) and the underlying mechanisms. Methods:

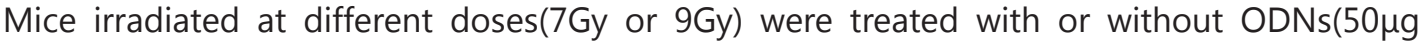
via intraperitoneal injection). Assays were performed to determine survival rate and the number of white blood cell in peripheral blood. The levels of granulocyte-colony stimulating factor(G-CSF), interleukin 6(IL-6) and interferon- $\alpha$ (IFN- $\alpha$ ) were measured using enzyme-linked immunosorbent assay (ELISA). Results: Survival rate of mice irradiated in 7Gy was increased from $50 \%$ to about $100 \%$ with ODNs pretreatment. ODNs administration increased the number of WBCs of irradiated mice. G-CSF, IL- 6 and IFN- $\alpha$ levels were up-regulated with ODNs treatment. Conclusion: All three classes of ODNs protected mice from irradiationinduced injuries. B-class ODNs exhibited the most potent radioprotective property via the up-regulation of G-CSF and IL-6.

\section{Introduction}

Exposure to ionizing radiation (IR) often causes severe damages to radiosensitive tissues. However, no effective safe drugs are currently available to protect IR-induced injuries. This inadequacy must be addressed.

Burdelya et al. reported that the ligand of toll-like receptor 5 (TLR5) exerted potent radioprotective effects on mice by activation of TLR5 and its downstream signaling pathway [1]. Our experiment subsequently demonstrated that TLR2, TLR4 and TLR9 exhibited

P. Zhang, S. Dong and J. Guo contributed equally to this work.

Xuejun Sun

and Jianming Cai 


\section{Cellular Physiology Cell Physiol Biochem 2017;44:2368-2377 \begin{tabular}{l|l|l|} 
and BOI: 10.1159/000486153 & $\begin{array}{l}\text { C) } 2017 \text { The Author(s). Published by S. Karger AG, Basel } \\
\text { www.karger.com/cpb }\end{array}$
\end{tabular} \\ Zhang et al.: Radioprotective Effects of Cpg-ODN in Mice}

potent radioprotective properties [2-4]. We also demonstrated that the TLR9 ligand CpGoligodeoxynucleotides (CpG-ODN) alleviated IR-induced injuries in mice.

The pattern recognition receptor toll-Like Receptor 9 (TLR9) recognizes bacterial DNA and synthetic ODN containing unmethylated CpG-ODN [5]. CpG-ODN activates B-lymphocyte and innate immune cells to secrete various cytokines and promote acquired immunity $[6,7]$. Three different kinds of CpG-ODN classes have been described [8, 9]. Phosphorothioate (PS)modified B-Class ODNs can effectively stimulate B and NK cells and exhibit antitumor activity $[10,11]$. A-class ODNs could induce considerably high levels of IFN- $\alpha$ from plasmacytoid dendritic cells [12]. The recently discovered C-class ODNs combine the properties of the $\mathrm{A}$ - and the B-classes in different species and induces potent B-cell activation comparable to B-Class ODN with IFN- $\alpha$ secretion comparable to A-Class ODN $[9,13]$.

Previous studies revealed that ODNs can protect mice from IR-induced injuries [14]. However, the functional difference between the three classes of ODNs is not clear. The present study compared the radioprotective properties of the three classes of ODNs and examined the underlying mechanisms. We found that the B-class exhibited the most potent alleviation of IR-induced injury via the up-regulation of G-CSF and IL-6.

\section{Materials and Methods}

\section{Oligodeoxynucleotides}

All ODNs (Fig. 1) were purchased from Sangon Biotech (Shanghai, China). ODNs were suspended in DEPC treated water, stored at $-20^{\circ} \mathrm{C}$ and handled under aseptic conditions. All dilutions were performed using pyrogen-free normal saline.

\section{Irradiation}

${ }^{60}$ Co- $\gamma$ rays at the Irradiation Center(Faculty of Naval Medicine, Second Military Medical University, China) were used for irradiation. Mice were exposed to varying doses of irradiation depending on the requirements of the study.

\section{Mice and treatments}

The Second Military Medical University in China approved all experiments in accordance with the Guide for Care and Use of Laboratory Animals published by the NIH (Publication No. 96-01,United States). Male wild-type BALB/c mice(6-8 weeks old) were purchased from the China Academy of Science (Shanghai, China). Mice were housed in individual cages in a temperature-controlled room with a $12 \mathrm{~h}$ light/dark cycle. Food and water were provided ad libitum.

White blood cell(WBC) count

Peripheral blood was collected from the retro-orbital simus/plexus using EDTA-coated blood collection tubes at different times after irradiation. White blood cells (WBCs) were detected using blood cell analyzer .

\section{ELISA}

Blood was collected and kept at room temperature for 30 minutes followed by centrifugation at $3000 \mathrm{rpm} / \mathrm{min}$ for $10 \mathrm{~min}$. Serum was removed and stored at $-20^{\circ} \mathrm{C}$. The levels of G-CSF, IFN- $\alpha$,and IL- 6 were detected in all samples by ELISA. All steps were performed in accordance with the manufacturer s' instructions.

\section{Statistical analysis}

Data are expressed as means \pm the standard error of mean (SEM) for each experiment. The number of samples is indicated in the description of each experiment. We used an analysis of variance (ANOVA) followed by a Student-Newman-Keuls post hoc test for statistical analysis. Experiments for quantification were performed in a blinded fashion and all experiments were repeated at least 3 independent times. 


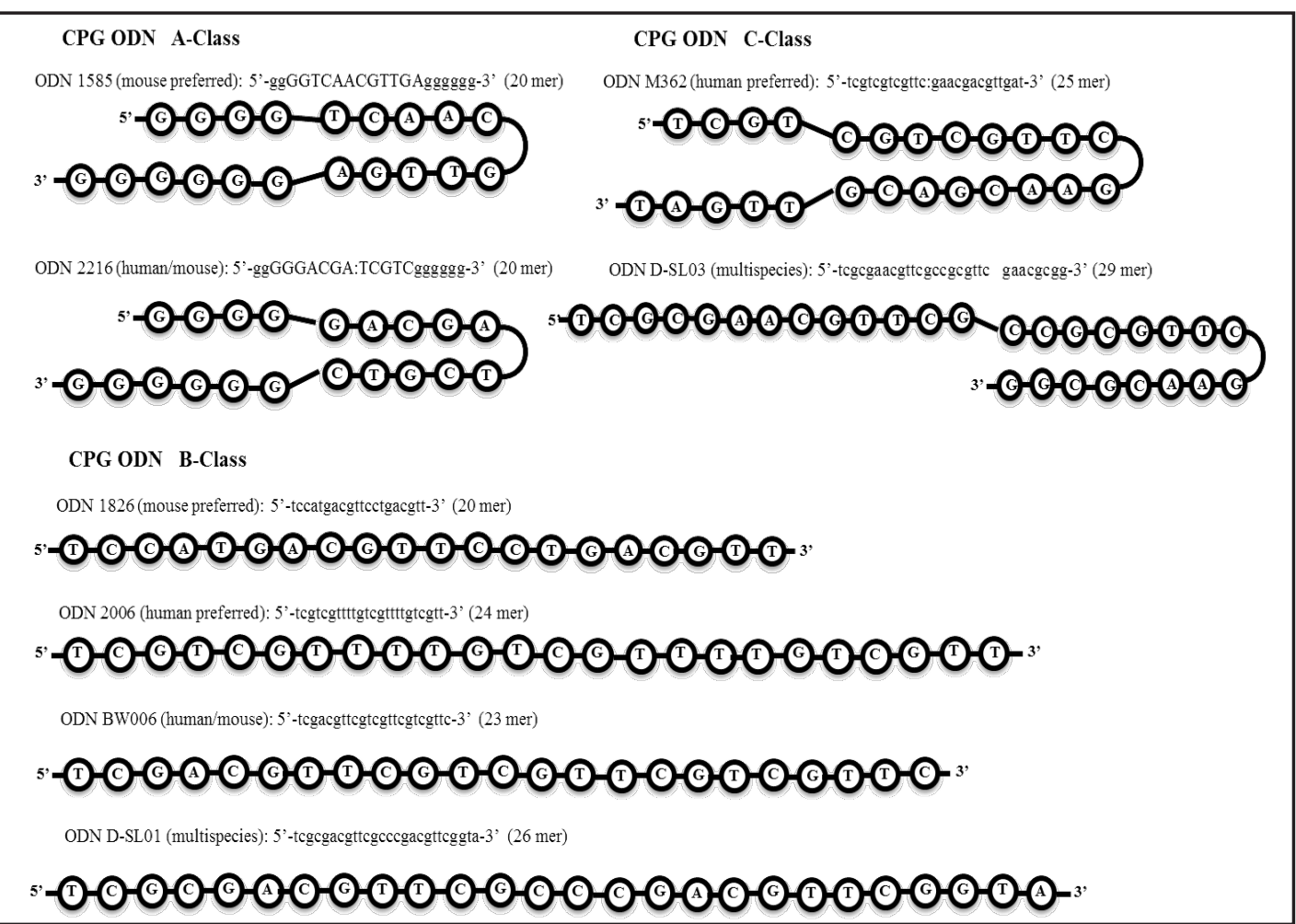

Fig. 1. Sequences of three classes of ODNs used in the study. A-class ODNs: ODN 1585 and ODN 2216. B-class ODNs: ODN 1826, ODN 2005,ODN BW006 and ODN D-SL01. C-class ODNs: ODN M362 and ODN D-SL03.

\section{Results}

Sequences of oligodeoxynucleotides used in the study

Three classes of ODNs with different properties were used in our study. ODN 1585 and ODN 2216 were A-class ODNs. ODN 1826, ODN 2005,ODN BW006 and ODN D-SL01 were B-class ODNs. ODN M362 and ODN D-SL03 were C-class ODNs. Fig. 1 shows the structure of all ODNs used.

\section{Survival rates of mice}

Mice were treated with different ODNs before or after different irradiation doses to evaluate the protective effects of ODNs on radiation injury. Mice were treated with $50 \mu \mathrm{g}$ ODNs via intraperitoneal injection (i.p.) $24 \mathrm{~h}$ and $2 \mathrm{~h}$ prior to whole body irradiation with a dose of $7 \mathrm{~Gy}$. The data indicated that $50 \%$ of irradiated mice without ODNs treatment died in 30 days, and more than $50 \%$ of mice pretreated with different ODNs survived (Fig. 2). Therefore, ODN pretreatment protected from radiation injury. B-class ODNs(ODN 1826 and ODN 7909) were the most potent property of the ODN classes.

We further investigated the protective effects of ODNs in mice treated with lethal irradiation(9Gy). The results demonstrated that all irradiated mice without ODN treatment died in 14 days. Mice pretreated with ODNs $24 \mathrm{~h}$ and $2 \mathrm{~h}$ before irradiation exhibited increased survival rate or prolonged survival time (Fig. 3). Administration of B-class ODNs(ODN 1826 and ODN 7909) increased survival rate most potently.

We also examined whether ODN treatment after irradiation mitigated radiation injury. Mice were treated with ODNs $30 \mathrm{~min}$ after $9 \mathrm{~Gy}$ radiation. Our data demonstrated that A-and C-class ODNs exerted no protective effects, and B-class ODNs markedly increased the survival rate (Fig. 4).

\section{KARGER}


Fig. 2. Survival rate of irradiated mice with 7 Gy was increased by the pretreatment with ODNs.
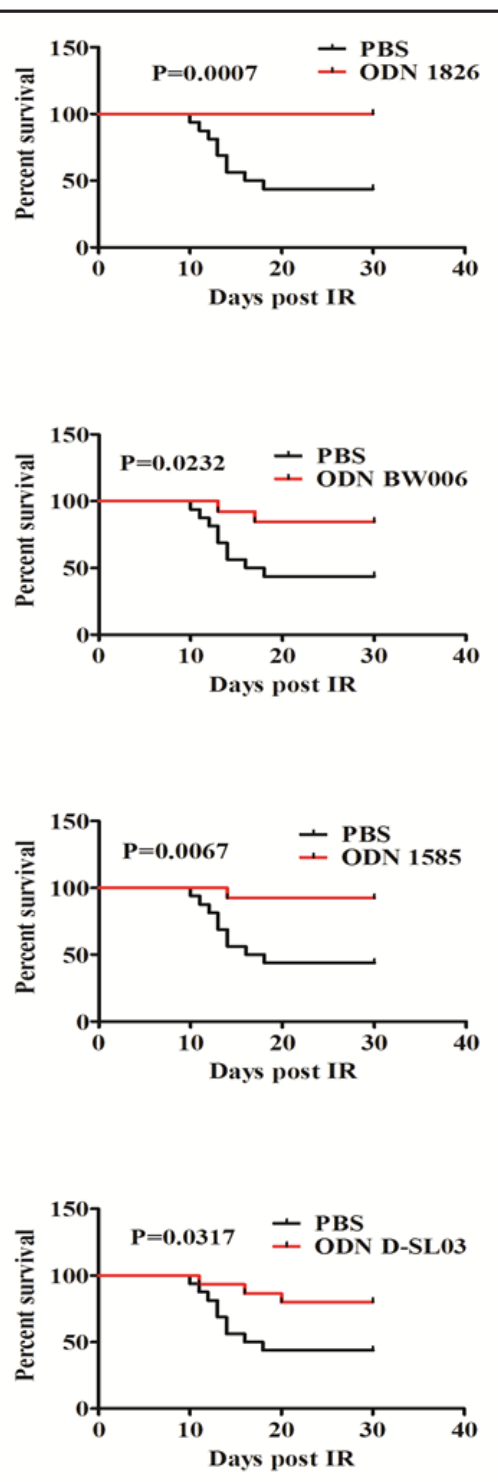
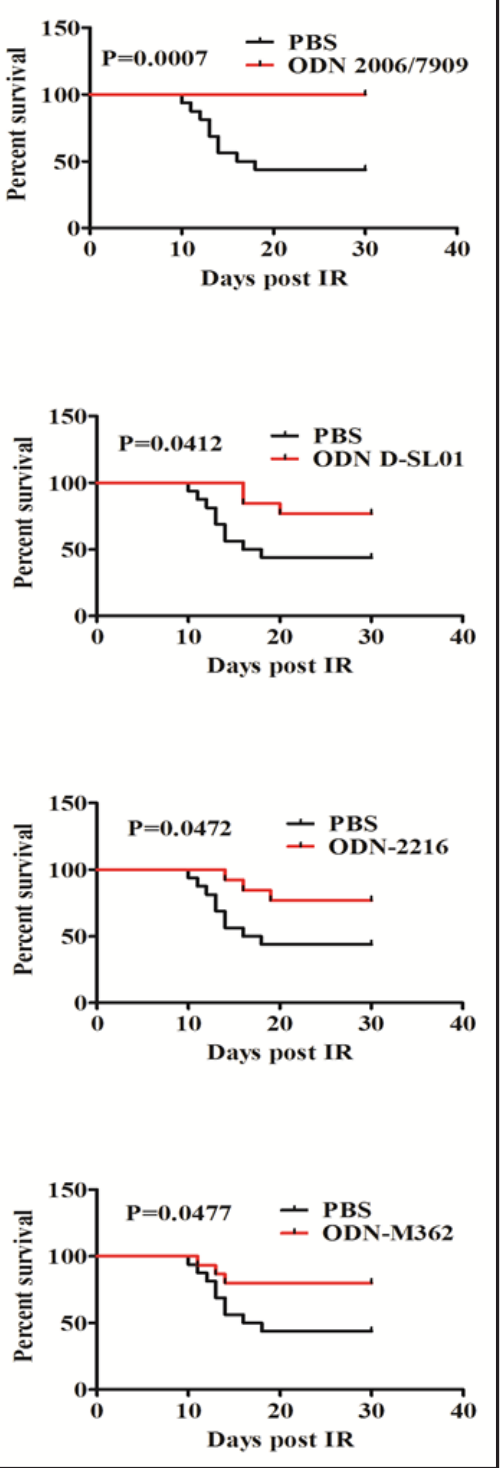

ODNs improved irradiation-induced decrease in peripheral WBC count

Treatment with 7Gy irradiation obviously decreased peripheral WBCs relative to the non-irradiated mice, and ODNs administration considerably improved WBC counts. B-class ODNs more potently improved the decrease in WBC compared to the other ODNs (Fig. 5A). Simple regression was used to detect the relationship between the number of WBCs and survival rate. Our data demonstrated that survival rate positively correlated to the number of WBCs (Fig. 5B).

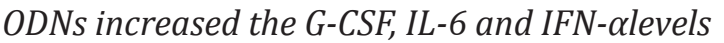

G-CSF, IL- 6 and IFN- $\alpha$ are key factors in radiation injuries. We examined the levels of G-CSF, IL- 6 and IFN- $\alpha$ in the serum of mice treated with different of $\mathrm{ODN}_{\mathrm{S}}$ in a radiation injury mice model to investigate the underlying mechanisms involved in the radioprotective properties of ODNs. We found that different ODNs induced different levels of G-CSF, IL-6 and IFN- $\alpha$ in mice (Fig. 6A). We analyzed correlations between mouse survival rates and the three cytokines levels and found that G-CSF and IL- 6 positively correlated with mouse survival separately (Fig 6B). However, IFN- $\alpha$ levels exhibited an insignificant negative correlation with mouse survival (Fig. 6C). Notably, removal of the outliers(blank and PBS-treated group) revealed that the IFN- $\alpha$ levels negatively correlated with mouse survival (Fig. 6D). 
Fig. 3. Survival rate of irradiated mice with 9Gy was increased by the pretreatment with ODNs.
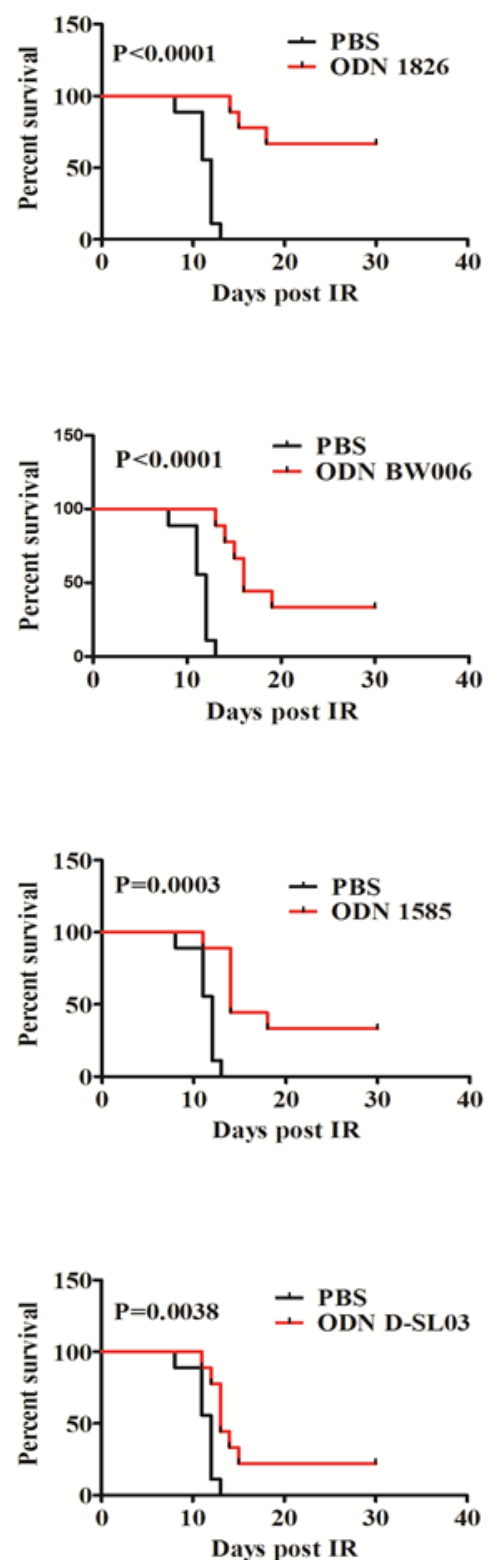
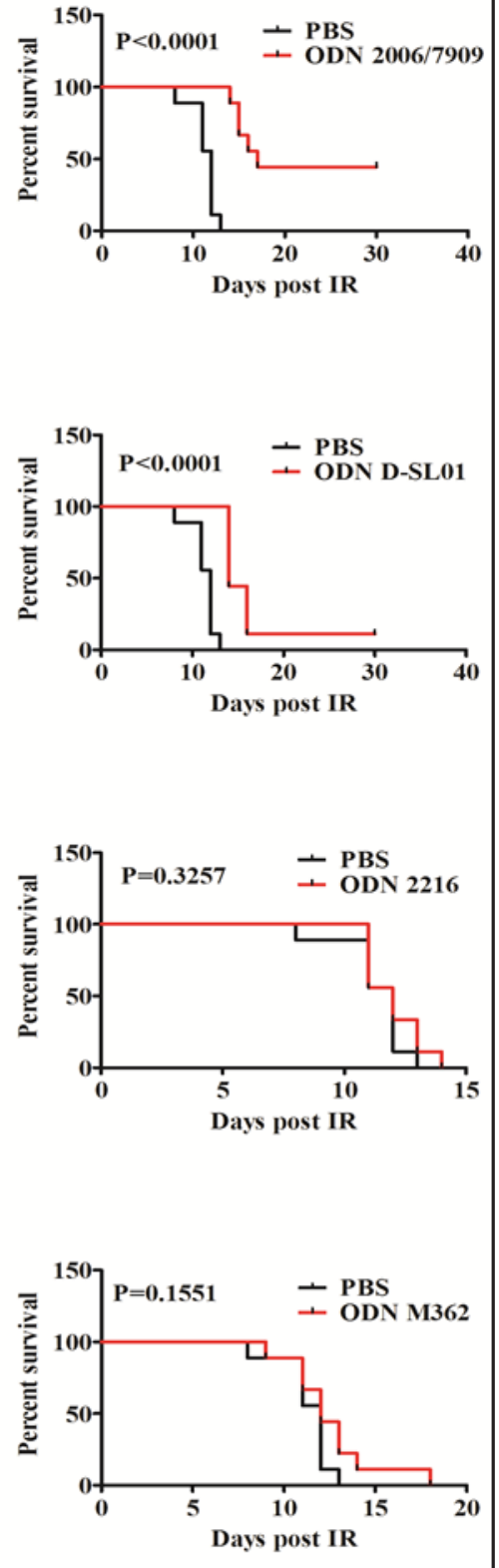

IFN- $\alpha$ and IL-6 deletion reduced the radioprotective property of B-class ODNs

The aforementioned results demonstrated that ODNs alleviated radiation injuries via cytokine regulations. In vivo experiments were performed to further confirm the result. Irradiated mice treated with B-class ODNs were treated with or without IFN- $\alpha$. The results demonstrated that the administration of IFN- $\alpha$ decreased survival rate (Fig. 7A). IL-6 knockout mice were treated with PBS or B-class ODNs, and the protective effect of B-class ODNs was not observed (Fig. 7B).

\section{Discussion}

Previous studies demonstrated that activation of the TLR signaling pathways possesses radioprotective properties. The TLR9 ligand CpG-ODN, also exerts radioprotective effects [4]. The present study demonstrated that all three classes of ODNs alleviated IR-induced 
Fig. 4. Survival rate of irradiated mice with 9Gy was increased by the posttreatment with ODNs.
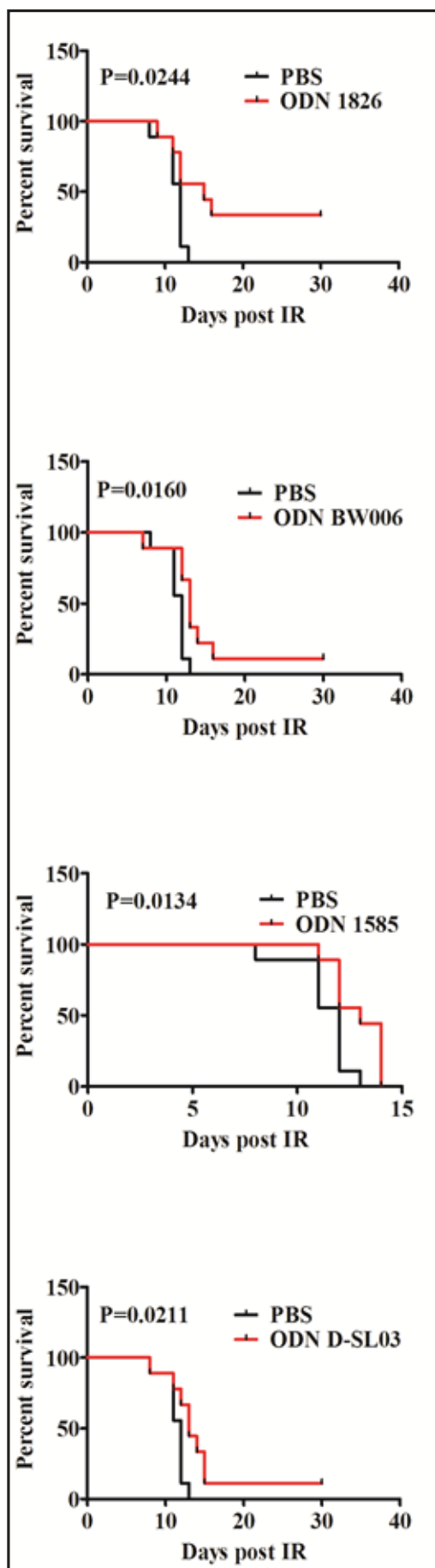
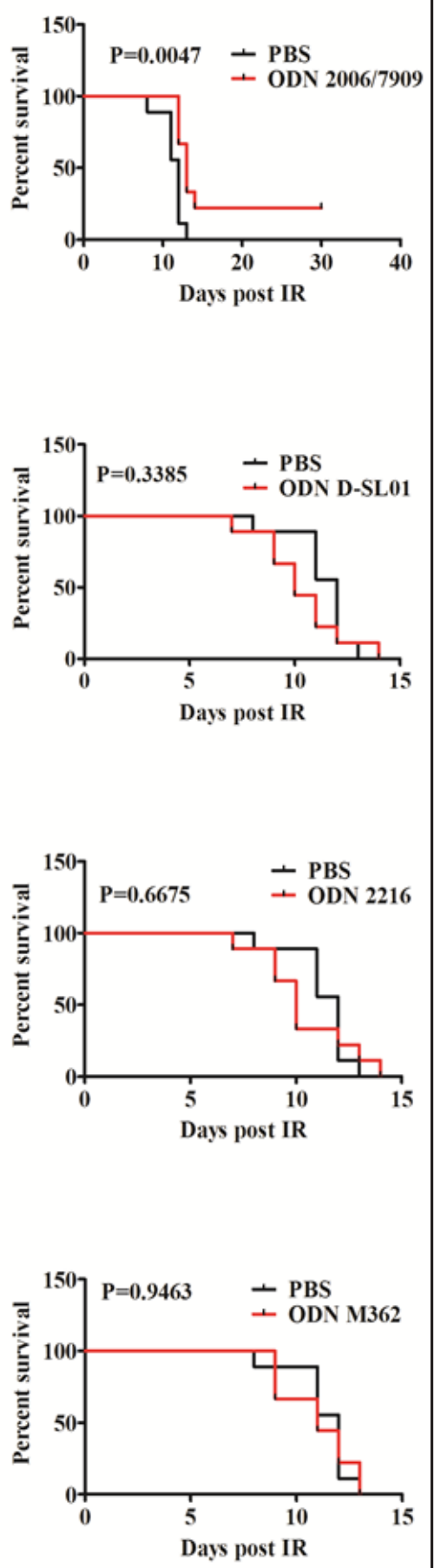

injuries in mice. ODNs increased the survival rate of mice treated with different doses of radiation. IR also resulted in severe injuries to radiosensitive tissues such as bone marrow tissue, and ODN treatment of ODNs markedly protected the number of WBCs in peripheral blood.

This study investigated the difference between the three classes of ODNs and found that $\mathrm{B}$-class ODNs showed the most potent radioprotective properties. Irradiated mice treated with B-class ODNs(ODN 1826 and ODN 7909) exhibited the highest survival rate and number of WBC. 
Fig. 5. ODNs improved irradiationinduced injuries of the peripheral white blood cell count. (A) Shown are the bar graphs of numbers white blood cell. (B) Simple regression of WBC number and survival rate.
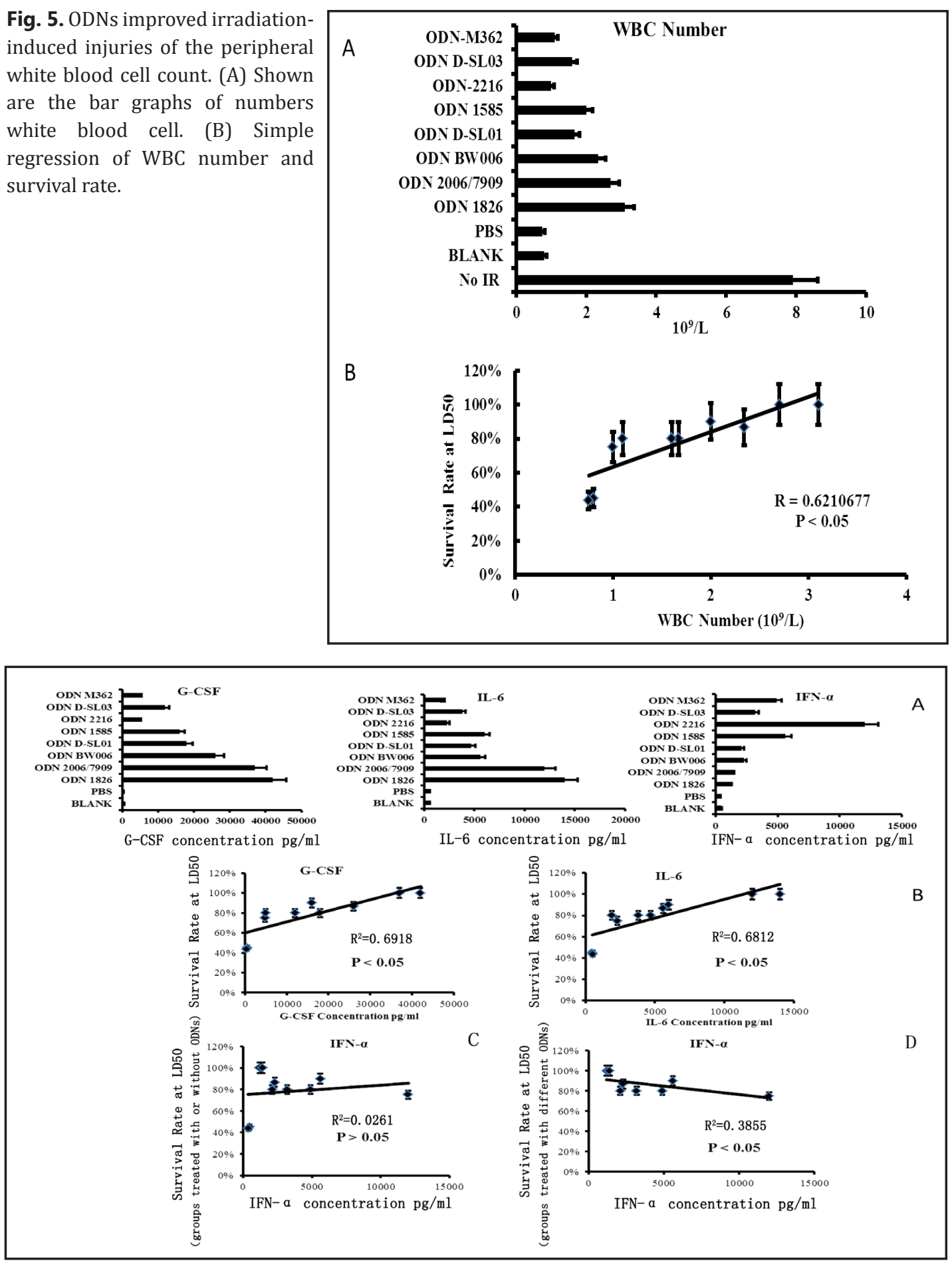

Fig. 6. ODNs increased the level of G-CSF, IL-6 and IFN- $\alpha$.(A) Shown are the bar graphs of concentration of different cytokines. (B) Simple regression of survival rate and different cytokines(G-CSF and IL-6). (C) Simple regression of survival rate and IFN- $\alpha$ in groups treated with or without ODNs(P>0.05) (D) Simple regression of survival rate and IFN- $\alpha$ in groups treated with different ODNs(except blank and PBS-treated group) $(\mathrm{P}>0.05)$.

We examined the mechanisms of the radioprotective effects of ODNs. IR induced severe injuries in hematopoietic tissue which may lead to death $[15,16]$. G-CSF and IL-6 

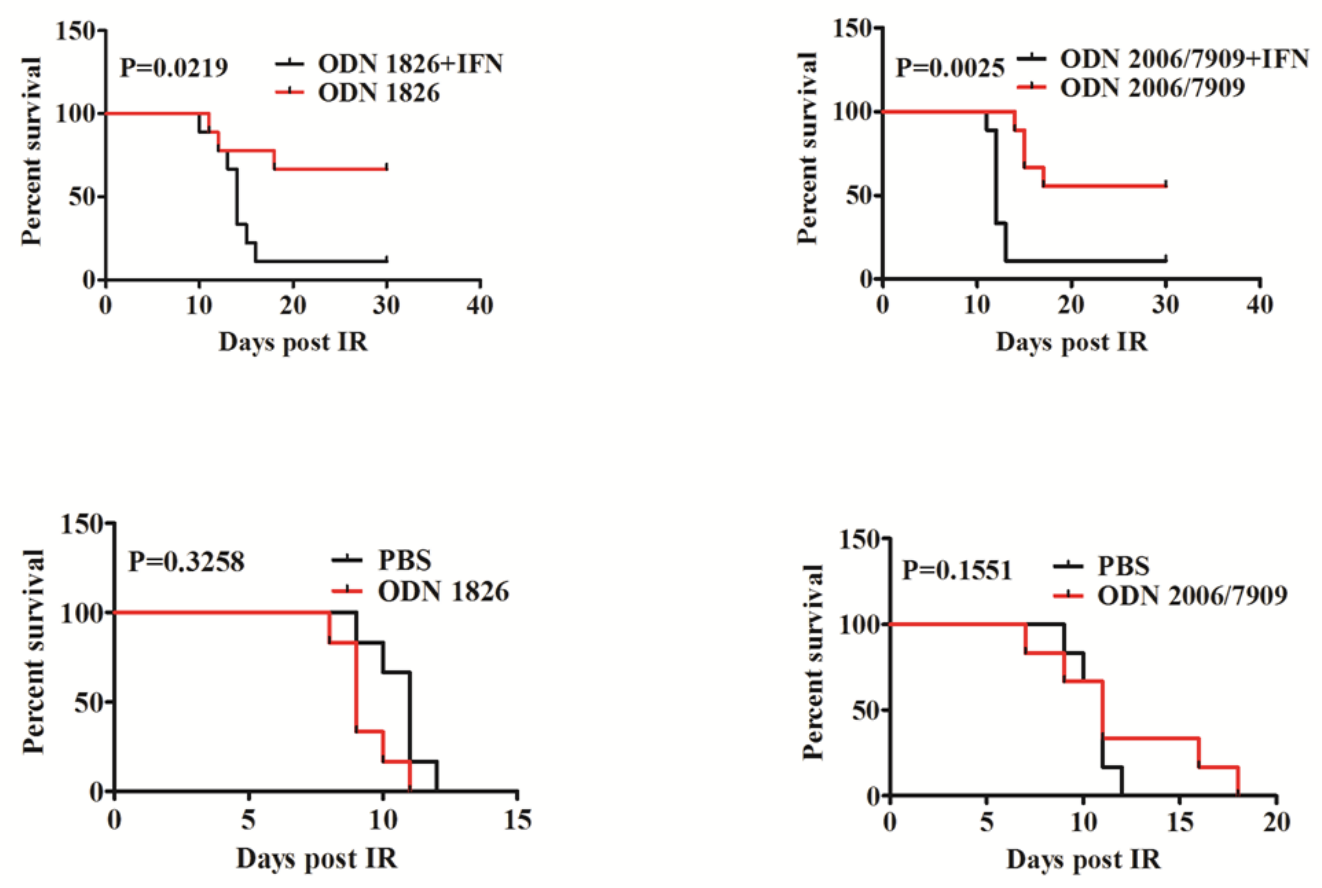

Fig. 7. Survival rate of mice. (A) Administration of IFN- $\alpha$ decreased the survival rate of irradiated mice with the treatment of B-class ODN. (B) Treatment of B-class ODNs showed no protective effect on the survival rate of irradiated IL-6 knock-out mice.

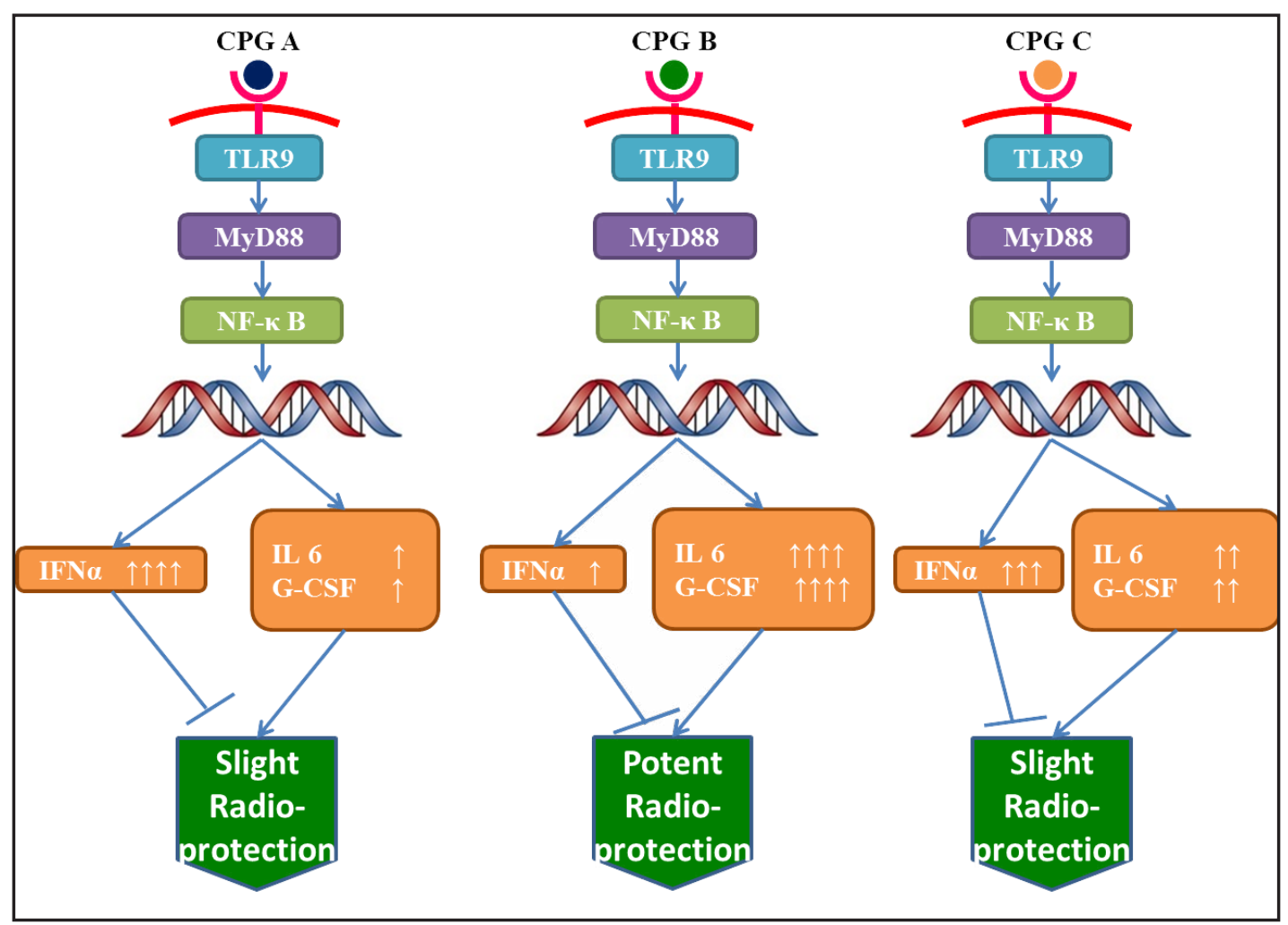

Fig. 8. Underlying mechanism of different classes of ODNs in radioprotection. 
are critical in hematopoiesis [17-20]. We demonstrated that G-CSF and IL-6 levels positively correlated to the survival rate of irradiated mice. Therefore, we determined the effects of ODNs on G-CSF and IL-6 levels. The results demonstrated that all three classes of ODNs upregulated G-CSF and IL-6 levels, which explained the radioprotective effects. B-class ODNs exhibited the most potent properties. ODNs induce moderate level of interferon(IFN), which is a cytokine implicated in virus defense and the resolution of infectious diseases [21-23]. Previous studies revealed that IFN- $\alpha$ potentiated radiation injury [24, 25]. The level of IFN- $\alpha$ was measured and we found that IFN- $\alpha$ was negatively correlated to the survival rate of irradiated mice. A- and C-class ODNs more effectively up-regulated IFN- $\alpha$ than B-class ODNs. These data demonstrated that B-class ODNs presented significant radioprotective properties resulting from the stronger ability to up-regulate G-CSF and IL- 6 and poorer ability to upregulate IFN- $\alpha$ than other classes of ODNs (Fig. 8).

\section{Conclusion}

This study demonstrated that ODNs effectively protected mice from IR-induced injuries. ODNs obviously increased the survival rate and the number of WBCs. B-class ODNs exhibited the most potent radioprotective properties and the most potent ability to up-regulate G-CSF and IL-6 levels.

\section{Acknowledgements}

This study was supported in part by the grants from National Natural Science Foundation of China (NO.81573092 and NO.11635014) and Innovation Program of Shanghai Municipal Education Commission (NO.15zz038).

\section{Disclosure Statement}

The authors have no conflicts of interest to disclose.

\section{References}

1 Burdelya LG, Krivokrysenko VI, Tallant TC, Strom E, Gleiberman AS, Gupta D, Kurnasov OV, Fort FL, Osterman AL, Didonato JA, Feinstein E, Gudkov AV: An agonist of toll-like receptor 5 has radioprotective activity in mouse and primate models. Science 2008;320:226-230.

- Gao F, Zhang C, Zhou C, Sun W, Liu X, Zhang P, Han J, Xian L, Bai D, Liu H, Cheng Y, Li B, Cui J, Cai J, Liu C: A critical role of toll-like receptor 2 (TLR2) and its' in vivo ligands in radio-resistance. Sci Rep 2015;5:13004.

3 Liu C, Zhang C, Mitchel RE, Cui J, Lin J, Yang Y, Liu X, Cai J: A critical role of toll-like receptor 4 (TLR4) and its' in vivo ligands in basal radio-resistance. Cell Death Dis 2013;4:e649.

4 Zhang C, Lin J, Cui J, Li B, Liu C, Wang J, Gao F, Cai J: Radioprotection of bone marrow hematopoiesis by CpGoligodeoxynucleotides administered to mice after total-body irradiation. J Radiat Res 2011;52:828-833.

5 Sohn WJ, Lee KW, Choi SY, Chung E, Lee Y, Kim TY, Lee SK, Choe YK, Lee JH, Kim DS, Kwon HJ: CpGoligodeoxynucleotide protects immune cells from gamma-irradiation-induced cell death. Mol Immunol 2006;43:1163-1171.

6 Krieg AM: CpG DNA: trigger of sepsis, mediator of protection, or both? Scand J Infect Dis 2003;35:653-659.

7 Gantner F, Hermann P, Nakashima K, Matsukawa S, Sakai K, Bacon KB: CD40-dependent and -independent activation of human tonsil B cells by CpG oligodeoxynucleotides. Eur J Immunol 2003;33:1576-1585.

8 Hartmann G, Battiany J, Poeck H, Wagner M, Kerkmann M, Lubenow N, Rothenfusser S, Endres S: Rational design of new $\mathrm{CpG}$ oligonucleotides that combine B cell activation with high IFN-alpha induction in plasmacytoid dendritic cells. Eur J Immunol 2003;33:1633-1641. 


\section{Cellular Physiology Cell Physiol Biochem 2017;44:2368-2377 \begin{tabular}{l|l|l}
\hline and Biochemistry 10.1159/000486153 & $\begin{array}{l}\text { C } 2017 \text { The Author(s). Published by S. Karger AG, Basel } \\
\text { www.karger.com/cpb }\end{array}$ \\
\hline
\end{tabular}}

Zhang et al.: Radioprotective Effects of Cpg-ODN in Mice

-9 Vollmer J, Weeratna R, Payette P, Jurk M, Schetter C, Laucht M, Wader T, Tluk S, Liu M, Davis HL, Krieg AM: Characterization of three $\mathrm{CpG}$ oligodeoxynucleotide classes with distinct immunostimulatory activities. Eur J Immunol 2004;34:251-262.

10 Hemmi H, Takeuchi O, Kawai T, Kaisho T, Sato S, Sanjo H, Matsumoto M, Hoshino K, Wagner H, Takeda K, Akira S: A Toll-like receptor recognizes bacterial DNA. Nature 2000;408:740-745.

11 Krieg AM, Yi AK, Matson S, Waldschmidt TJ, Bishop GA, Teasdale R, Koretzky GA, Klinman DM: CpG motifs in bacterial DNA trigger direct B-cell activation. Nature 1995;374:546-549.

12 Krieg AM: CpG motifs in bacterial DNA and their immune effects. Annu Rev Immunol 2002;20:709-760.

$>13$ Abel K, Wang Y, Fritts L, Sanchez E, Chung E, Fitzgerald-Bocarsly P, Krieg AM, Miller CJ: Deoxycytidyldeoxyguanosine oligonucleotide classes A, B, and C induce distinct cytokine gene expression patterns in rhesus monkey peripheral blood mononuclear cells and distinct alpha interferon responses in TLR9expressing rhesus monkey plasmacytoid dendritic cells. Clin Diagn Lab Immunol 2005;12:606-621.

14 Zhang C, Ni J, Li BL, Gao F, Liu H, Liu W, Huang YJ, Cai JM: CpG-Oligodeoxynucleotide Treatment Protects against Ionizing Radiation-Induced Intestine Injury. PLoS One 2013;8:e66586.

15 Rendon DA, Kotedia K, Afshar SF, Punia JN, Sabek OM, Shirkey BA, Zawaski JA, Gaber MW: Mapping Radiation Injury and Recovery in Bone Marrow Using 18F-FLT PET/CT and USPIO MRI in a Rat Model. J Nucl Med 2016;57:266-271.

16 Chen Y, Xu Y, Du J, Guo J, Lei X, Cui J, Liu C, Cheng Y, Li B, Gao F, Ju J, Cai J, Yang Y: Radioprotective Effects of Heat-Killed Mycobacterium Tuberculosis in Cultured Cells and Radiosensitive Tissues. Cell Physiol Biochem 2016;40:716-726.

17 Petit I, Szyper-Kravitz M, Nagler A, Lahav M, Peled A, Habler L, Ponomaryov T, Taichman RS, ArenzanaSeisdedos F, Fujii N, Sandbank J, Zipori D, Lapidot T: G-CSF induces stem cell mobilization by decreasing bone marrow SDF-1 and up-regulating CXCR4. Nat Immunol 2002;3:687-694.

-18 Schneider A, Kruger C, Steigleder T, Weber D, Pitzer C, Laage R, Aronowski J, Maurer MH, Gassler N, Mier W, Hasselblatt M, Kollmar R, Schwab S, Sommer C, Bach A, Kuhn HG, Schabitz WR: The hematopoietic factor G-CSF is a neuronal ligand that counteracts programmed cell death and drives neurogenesis. J Clin Invest 2005;115:2083-2098.

19 Ikebuchi K, Wong GG, Clark SC, Ihle JN, Hirai Y, Ogawa M: Interleukin 6 enhancement of interleukin 3-dependent proliferation of multipotential hemopoietic progenitors. Proc Natl Acad Sci U S A 1987;84:9035-9039.

20 Herodin F, Mestries JC, Janodet D, Martin S, Mathieu J, Gascon MP, Pernin MO, Ythier A: Recombinant glycosylated human interleukin- 6 accelerates peripheral blood platelet count recovery in radiationinduced bone marrow depression in baboons. Blood 1992;80:688-695.

21 Krug A, Rothenfusser S, Hornung V, Jahrsdorfer B, Blackwell S, Ballas ZK, Endres S, Krieg AM, Hartmann G: Identification of CpG oligonucleotide sequences with high induction of IFN-alpha/beta in plasmacytoid dendritic cells. Eur J Immunol 2001;31:2154-2163.

-22 Ballas ZK, Rasmussen WL, Krieg AM: Induction of NK activity in murine and human cells by CpG motifs in oligodeoxynucleotides and bacterial DNA. J Immunol 1996;157:1840-1845.

-23 Berghofer B, Haley G, Frommer T, Bein G, Hackstein H: Natural and synthetic TLR7 ligands inhibit CpG-Aand CpG-C-oligodeoxynucleotide-induced IFN-alpha production. J Immunol 2007;178:4072-4079.

-24 Dritschilo A, Mossman K, Gray M, Sreevalsan T: Potentiation of radiation injury by interferon. Am J Clin Oncol 1982;5:79-82.

25 Angioli R, Sevin BU, Perras JP, Untch M, Koechli OR, Nguyen HN, Steren A, Schwade JG, Villani C, Averette HE: In vitro potentiation of radiation cytotoxicity by recombinant interferons in cervical cancer cell lines. Cancer 1993;71:3717-3725. 